\title{
SUPERVISI KUNJUNGAN KELAS \\ SEBAGAI UPAYA MEMBINA PROFESIONAL GURU SLTP/SLTA
}

\author{
Suto Prabowo, Dyah Satya Yoga
}

\begin{abstract}
Abstrak
Supervisi merupakan kegiatan pembinaan yang dilakukan kepala sekolah kepada guru untuk membantu memperbaiki situasi pembelajaran agar para siswa dapat belajar lebih efektif dengan prestasi belajar yang meningkat.

Supervisi kunjungan kelas adalah salah satu teknik supervisi yang dilakukan kepala sekolah dengan cara mengunjungi kelas untuk mengamati secara langsung bagaimana performa guru dalam pembelajaran serta membantu meningkatkan proses pembelajaran sehingga hasil belajar siswa semakin baik. Proses pembelajaran (instruction) adalah kegiatan yang dilakukan guru untuk membantu siswa belajar. Dalam proses pembelajaran di kelas siswa dianggap telah belajar apabila tujuan pelajaran yang dirumuskan (TPK) telah dikuasai oleh siswa. Peran guru sangat besar dalam proses pembelajaran karena sebagai penanggung jawab dan sebagai pengelola proses pembelajaran di kelas. Kinerja Guru adalah hasil pekerjaan yang dikerjakan sesuai dengan tuntutan profisi guru, yang ditunjukkan dengan produktivitas kerja tinggi yang semakin lama semakin baik dan bermutu.
\end{abstract}

Kata kunci: Supervisi Kunjungan Kelas, Upaya membina, Profesi Guru.

Kegiatan supervisi pada dasarnya adalah proses pembimbingan yang dilakukan kepala sekolah dan guru senior kepada guru dan para personalia sekolah lainnya yang langsung menangani belajar para siswa untuk memperbaiki situais belajar mengajar, agar para siswa dapat belajar secara efektif dengan prestasi belajar yang semakin meningkat (Pidarta, 1999). Supervisi merupakan kegiatan pembimbingan yang bersifat manusiawi melalui hubungan yang demokratis, keterbukaan dan persahabatan (Bafadal, 1992). Selain itu kegiatan supervisi direncanakan untuk membantu guru dalam memberikan pengajaran kepada siswa agar aktif belajar sehingga tujuan organisasi sekolah dapat tercapai.

Para personalia yang bertanggung jawab terhadap tujuan sekolah menggunakan supervisi untuk membantu personalia yang lain dalam menuntaskan tujuan sekolah yang ditetapkan, sebagaimana dikemukakan Segiovanni (1971) demikian: "Supervisor is a process used by those in school who have responsibility for one or another aspect of the school's goals and who depend directly others to help them achieve these goals".

jsh Jurnal Sosial Humaniora, Vol 9 No.1, Juni 2016 
Neagley (1993) berpendapat bahwa supervisi sebagai pelayanan kepada para guru yang bertujuan menghasilkan perbaikan instruksional, belajar dan kurikulum "Modern supervition is considered as any service for that teacher eventually result in improving instruction, learning and curriculum".

Sejalan dengan pendapat Neagley (1993), maka Sutjipto dan Mukti (1992) menyatakan bahwa supervisi yang dilakukan kepala sekolah adalah membantu para guru untuk (1) pengambangan kurikulum, (2) pengorganisasian pengajaran, (3) pemenuhan fasilitas belajar, (4) perencanaan dan pemerolehan bahan pengajaran sesuai dengan rancangan kuriulum, (5) perancangan dan implementasi dalam meningkatkan pengalaman belajar, (6) pengkoordinasian kegiatan belajar mengajar dengan kegiatan lain, (7) pelaksanaan evaluasi pengajaran, (8) pengembangan hubungan dengan masyarakat.

Franseth (1961) memandang supervisi sebagai kegiatan memimpin (leadership) yang melibatkan semua personalia sekolah dalam semangat kerjasama untuk mencapai program sekolah yang optimal. "Today supervision is generally seen as leadership that encourages a continous involment of all school in a cooperative attempt the most school program".

Dari paparan-paparan tersebut dapat disimpulkan hakikat supervisi adalah upaya pembimbingan yang dilakukan kepala sekolah, guru senior, penilik dan pengawas sekolah kepada guru-guru dan para personalia sekolah lainnya untuk meningkatkan kualitas proses pembelajaran dan hasil belajar siswa serta situasi belajar mengajar secara efektif, sehingga mutu dan tujuan pendidikan dapat tercapai.

Pidarta (1999), menguraikan fungsi dan tujuan supervisi secara rinci sebagai berikut:

\section{a. Fungsi Supervisi}

Fungsi supervisi dibedakan menjadi 2 bagian, yaitu :

1. Fungsi utama untuk membantu perkembangan individu para siswa.

2. Fungsi tambahan untuk membina para guru agar dapat bekerja lebih baik dalam rangka menyesuaikan diri dengan tuntutan masyarakat serta mempelopori kemajuan masyarakat. 
Yang termasuk fungsi utama ialah :

a. Supervisi fungsinya tidak dapat dipisahkan dengan administrasi, keduanya terkoordinasi dan saling menunjang dalam melaksanakan sistem pendidikan.

b. Supervisi mengkoordinasi personalia sekolah terutama para guru dan aktivitas-aktivitas sekolah agar tidak menyimpang dari perencanaan semula.

c. Supervisi memperlancar proses belajar mengajar dengan memperhatikan beberapa segi dari proses intruksional, yaitu : (1) Perencanaan intruksional perlu disesuaikan dengan tujuan, situasi sekolah, sumber-sumber pendidikan dan keadaan siswa, (2) Model belajar yang mungkin dilaksanakan, (3) Sarana dan alat-alat pendidikan yang perlu disiapkan, metode pembelajaran yang cocok, (4) situasi belajar yang cocok untuk mempelajari bidang studi tertentu, (5) Macam evaluasi dan alat evaluasi yang akan dilaksanakan.

d. Mengendalikan usaha guru mendidik para siswa agar siswa berkembang scara total, setiap aspek individu berkembang seimbang, harmonis dan optimal (afeksi, kognisi dan psikomotor).

e. Memberikan bantuan pemikiran guru dalam bimbingan karir bagi siswa yang sesuai dengan bakat, minat dan tingkat kemampuannya.

Adapun fungsi supervisi tambahan, fungsi yang tidak secara langsung menyangkut proses belajar mengajar, adalah sebagai berikut :

a. Memotivasi guru agar tetap bekerja dengan baik pada setiap situasi dan kondisi.

b. Memberi dorongan kepada guru untuk dapat bekerja secara kreatif, tidak bekerja secara monoton, dengan mencari cara-cara baru yang lebih baik dalam membimbing siswa belajar.

c. Memberikan teladan bagi guru-guru dalam membawa diri sebagai pendidik, dalam kemauan, semangat bekerja dan kepribadian. 
d. Melalui supervisi, para supervisor menegakkan disiplin kerja guruguru.

e. Mendampingi para guru dalam penelitihan-penelitihan tentang pengembangan kurikulum dan bidang studi. Supervisor bertindak sebagai konsultan.

f. Untuk menghimbau gury-guru berusaha meningkatkan profesinya.

g. Supervisor berkewajiban menghubungkan sekolah dengan masyarakat, menyesuaikan diri dan mempertimbangkan tuntutan masyarakat serta menjadi agen pembaharuan masyarakat.

h. Supervisor menjadi agen informasi pendidikan yang bersumber dari luar sekolah, agar sekolah tidak terlambat mempersiapkan diri menghadapi perubahan-perubahan dan dinamika sosial.

b. Tujuan Supervisi

Tujuan supervisi menurut Sergiovanni (dalam Pidarta, 1999) ialah :

1) Tujuan akhir adalah untuk mencapai pertumbuhan dan perkembangan para siswa (yang bersifat total). Dengan demikian sekaligus akan dapat memperbaiki masyarakat.

2) Tujuan kedua adalah membantu kepala sekolah dalam menyesuaikan program pendidikan dari waktu ke waktu secara kontinu dalam rangka menghadapi tatntangan perubahan zaman.

3) Tujuan dekat adalah bekerjasama mengembangkan proses belajar mengajar yang tepat.

4) Tujuan perantaraan adalah membina guru-guru agar dapat mendidik para siswa dengan baik, atau menegakkan disiplin kerja secara manusiawi.

Dalam melaksanakan supervisi kepala sekolah perlu berpedoman pada prinsipprinsip supervisi yaitu :

a. Supervisi bersifat ilmiah, yakni memenuhi tiga kriteria : sistematik, obyektif dan faktual. 
b. Supervisi dilakukan berdasarkan prinsip demokratis, bukan karena takut atau karena intimidasi atasan, dilakukan atas dasar kekeluargaan, melalui musyawarah, saling memberi dan menerima.

c. Supervisi dilakukan dengan cara bekerjasama (kooperatif) dan selalu mengarahkan kegiatannya untuk mencapai tujuan bersama dengan menciptakan situasi belajar mengajar yang lebih baik.

d. Supervisi bukan dilakukan dengan cara instruktif, melainkan atas dasar kreativitas dan inisiatif guru sendiri di mana supervisor hanya memberikan contoh dan dorongan agar tercipta situasi belajar mengajar yang leih baik.

e. Supervisi dilakukan secara terbuka, tidak sembunyi-sembunyi, melainkan dengan cara terus terang melalui pemberitahuan resmi atau tidak resmi, sehingga guru yang akan disupervisi mengetahui terlebih dulu bahwa dirinya akan disupervisi.

f. Supervisi hendaknya dilakukan secara profesional, berkesinambungan dan teratur sehingga diharapkan tercipta self supervision. (Arikunto, 1989).

Disamping prinsip di atas, sikap supervisor yang bijaksana sangat mendukung pelaksanaan supervisi yang efektif, yaitu :

a. Berperilaku ramah dan tulus dalam memperhatikan seluruh guru sebagai orang profesional dan sebagai pribadi.

b. Memfokuskan perhatian terutama pada kebutuhan guru dan segala teknik mengajar.

c. Memberi kesempatan kepada guru untuk memperkaya pengalaman tanpa tekanan.

d. Membuat situasi dan kondisi yang sesuai dengan perilaku dan watak berbagai manusia secara sosial.

e. Memuji dan mendorong sikap dan prosedur yang baik terhadap pengajaran dengan melakukan berbagai pertimbangan serta partisipasi dari guru.

f. Ada usaha merefleksi diri demi perkembangan cara penyampaian pelajaran (Hariwung, 1989).

Selanjutnya Depdikbud (1994) memberikan Petunjuk Pelaksanaan Supervisi Pendidikan di Sekolah, sebagai berikut : 
a. Sistematis, artinya supervisi dikembangkan dengan perencanaan yang matang sesuai dengan sasaran yang diinginkan.

b. Obyektif artinya supervisi memberikan masukan sesuai dengan aspek yang terdapat dalam instrument.

c. Realistis artinya supervisi didasarkan atas kenyataan sebenarnya yaitu pada keadaan atau hal-hal yang sudah dipahami dan dilakukan oleh para staf sekolah.

d. Antisipasi artinya supervisi diarahkan untuk menghadapi kesulitan-kesulitan yang mungkin akan terjadi.

e. Konstruktif artinya memberikan saran-saran perbaikan kepada yang disupervisi untuk berkembang sesuai ketentuan atau aturan yang berlaku.

a. Fungsi Supervisi Kunjungan Kelas

Supervisi kunjungan kelas dipakai untuk mengumpulkan data lebih banyak dan lebih objektif, sebagai latihan, untuk membina kemampuan dan keterampilan guru, sebagai evaluasi untuk melihat sampai dimana kemajuan yang telah diproses guru. Dalam kunjungan kelas supervisor dapat menolong guru mengerjakan sesuatu, kadang-kadang juga menolong siswa yang menghadapi kesulitan kelas.

Menurut Neagley (dalam Pidarta, 1999), tujuan teknik kunjungan kelas ialah:

1) Membantu guru yang belum berpengalaman.

2) Membantu guru yang sudah berpengalaman tentang kekeliruan yang dia lakukan.

3) Membantu guru pindahan yang belum jelas tentang situasi dan kondisi kelas yang diajarinya.

4) Membantu melaksanakan proyek-proyek pendidikan.

5) Mengamati perilaku guru pengganti.

6) Mendengarkan nara sumber mengajar.

7) Mengamati tim pengajar melaksanakan tugasnya pada siswa-siswa dalam kelompok kecil dan kelompok besar. 
8) Mengamati cara mengajar bidang studi yang istimewa.

9) Membantu menilai pemakaian media pendidikan.

Beberapa hal yang perlu diperhatikan dalam melaksanakan kunjungan kelas adalah :

1) Kunjungan dapat dilakukan dengan memberitahu atau tidak memberitahu, tergantung pada sifat tujuan dan masalahnya.

2) Kunjungan dapat juga atas permintaan sekolah atau guru yang bersangkutan.

3) Sudah memiliki pedoman tentang hal-hal yang akan dilakukan dalam kunjungan tersebut baik berupa instrumen atau catatan-catatan.

4) Sasaran kunjungan dan tujuan sudah cukup jelas (Depdikbud ; 1996:21)

Kunjungan kelas memerlukan persiapan, baik oleh supervisor yang akan mengadakan kunjungan, maupun oleh guru yang akan dikunjungi. Dengan mempersiapkan diri terlebih dahulu, supervisor akan lebih mudah mengarahkan

1) Untuk mengetahui sampai dimana guru berusaha melaksanakan program cawu, dan berusaha melaksanakan saran-saran saerta anjuran yang pernah diberikan oleh kepala sekolah.

2) Untuk menimbulkan pengertian dan kepercayaan pada guru terhadap supervisi. Dengan sering mendapatkan kunjungan, para guru akan lebih menyadari fungsi supervisi sebagai usaha membantu meningkatkan kemampuan mereka.

3) Untuk menimbulkan rasa persatuan dan kesatuan diantara guru-guru, supaya mereka tidak lagi bekerja hanya untuk kepentingan kelasnya atau diri sendiri saja, tetapi menyadari pentingnya tujuan sekolah yang harus dicapai bersama.

4) Untuk memperoleh data yang diperlukan dalam tindakan-tindakan administratif, yaitu dalam usaha menyediakan fasilitas dan sarana yang diperlukan untk membina situasi belajar mengajar yang baik. 
b. Ciri-ciri teknik supervisi kunjungan kelas

Menurut Pidarta (1999) dan 5 karakteristik teknik supervisi kunjungan kelas, yaitu:

1) Melakukan sejumlah kunjungan pendek yaitu 5-10 menit untuk satu kelas.

2) Bisa juga mengunjungi beberapa kelas dalam satu hari.

3) Supervisor berpartisipasi dalam proses belajar mengajar.

4) Supervisor dapat membantu atau menolong guru dalam proses belajar mengajar.

5) Pada saat-saat tertentu supervisor juga menolong siswa yang menghadapi kesulitan.

Setelah kunjungan kelas selesai, selanjutnya diadakan pertemuan balikan antara supervisor dengan guru yang bersangkutan. Supervisor memberikan saran atau nasihat yang diperlukan, guru dapat mengajukan pendapat serta usul-usul yang konstruktif demi perbaikan proses belajar mengajar selanjutnya.

c. Langkah-langkah supervisi kunjungan kelas

Pelaksanaan supervisi kunjungan kelas dilakukan secara terencana, artinya segala sesuatu yang berkaitan dengan supervisi kunjungan kelas terlebih dahulu dipersiapkan dengan baik. Langkah-langkah pelaksanaan supervisi kunjungan kelas seperti diungkapkan oleh Pidarta (1999) sebagai berikut:

1) Perencanaan

Perencanaan supervisi kunjungan kelas meliputi :

a) Ynag perlu diamati dalam proses pembelajaran antara lain perangkat pembelajaran, pengelolaan kelas, penggunaan alat peraga, penyampaian konsep-konsep.

b) Waktu kunjungan, yaitu kapan supervisi dilakukan

c) Pemilihan kelas dan guru yang mengajar di kelas itu

2) Menentukan instrument observasi, seperti alat tulis menulis dan pedoman-pedoman observasi yang diperlukan 
3) Mengobservasi di kelas, yaitu untuk mengetahui lebih jauh kesulitan-kesulitan yang dihadapi oleh guru dan siswa dalam proses pembelajaran.

4) Kemungkinan berpartisipasi

a) Terhadap guru, membantu guru dalam menghadapi masalahmasalah yang ada dalam proses pembelajaran, misalnya dalam penguunaan media pembelajaran.

b) Terhadap siswa, membantu siswa dalam mengatasi kesulitankesulitan belajar, misalnya memecahkan masalah yang dihadapi siswa dalam proses belajar mengajar, yaitu mengemukakan pendapat, bertanya atau menjawab pertanyaan.

5) Pertemuan balikan, adalah tindak lanjut setelah melakukan kunjungan kelas dan sesudah mengumpulkan data sebagai informasi.

\section{Profesi Guru}

\section{Pengertian Profesi Guru}

Profesi adalah pekerjaan dari sebuah jabatan, yang menuntut keahlian tertentu serta memiliki etika khusus untuk jabatan tersebut serta memberi pelayanan baku terhadap masyarakat (Tilaar, 2000). Profesi dijalankan berdasarkan ilmu pengetahuan khusus yang diperoleh melalui pendidikan akademis yang intensif dan lama (Soetjipto, 1990).

Seseorang dikategorikan professional bila memiliki keahlia tertentu dan menjalankan pekerjaanya sesuai dengan tuntutan profesi, atau dengan kata lain memiliki kemampuan dan sikap sesuai dengan tuntutan profesinya. Oleh karena itu seorang profesional akan terus menerus meningkatkan mutu karyanya melalui pendidikan dan pelatihan (Tilaar, 2002).

Untuk mengembangkan suatu bidang pekerjaan atau jabatan secara profesional, pekerjaan yang dihasilkan harus berdasarkan kriteria-kriteria profesi yang terus menerus berkembang sehingga tingkat keahlian, tingkat 
tanggung jawab (etos kerja), etika profesi, serta perlindungan terhadap profesi terus menerus dapat disempurnakan. Dengan demikian proses profesionalisasi ditunjukkan melalui produktivitas kerja yang tinggi serta mutu karya yang semakin lama semakin baik (Kundji, 1998).

Suatu pekerjaan atau jabatan digolongkan sebagai profesi apabila memiliki kriteria-kriteria profesi, yaitu: (1) Profesi didasarkan atas pengetahuan yang spesifik, (2) Profesi mengejar kemajuan para anggotanya, (3) Profesi melayani kebutuhan para angotanya yang meliputi kesejahteraan dan profesional, (4) Profesi memiliki norma-norma etis, (5) Profesi mempengaruhi kebijaksanaan di bidangnya mengenai perubahan dalm kurikulum, struktur organisasi pendidikan, (6) Profesi mempunyai solidaritas kelompok profesi (Soetjipto, 1999).

Kriteria bagi profesi di bidang pendidikan dikemukakan pula oleh Sutisna (1993) demikian: (1) Profesi memiliki sejumlah pengetahuan yang unik, yang dikuasai dan dipraktekkan oleh para anggotanya, (2) Profesi memiliki suatu ikatan yang kuat dari para anggotanya, (3) Profesi memiliki kode etik yang dapat memaksa para anggota untuk mengambil pola kelakuan tertentu, (4) Profesi memberikan jasa kepada masyarakat.

Indikator-indikator Profesi Guru

Sebelum guru menjadi matang atau profesional dalam mempersiapkan dan melaksanakan tugas jabatan/profesi, ia membutuhkan perhatian, bantuan dan bimbingan yang diberikan oleh kepala sekolah atau wakil kepala sekolah. Sebagai supervisor, kepala sekolah bertanggung jawab untuk membina guruguru agar selalu berusaha meningkatkan profesinya.

Pidarta (1999) mengungkapkan bahwa fungsi supervisi adalah membina guru-guru agar dapat bekerja dengan baik, dalam membantu perkembangan individu para siswa, menyesuaikan diri dengan tuntutan masyarakat serta mempelopori kemajuan masyarakat. Supervisi sebagai pembinaan menunjukkan sebagai kegiatan membimbing yang dilakukan bukan secara otoriter agar pekerjaan cepat berhasil, tetapi melalui pendidikan humanistik, kolaburatif (kerja sama), terbuka dan fleksibel. 
Pembinaan yang dilakukan kepada kepala sekolah sebagai bentuk pendidikan in service, setelah guru diangkat sebagai tenaga pendidik di sekolah, merupakan kelanjutan pendidikan pre-service, yang bertujuan agar guru-guru dapat menyesuaikan dengan perkembangan dan perubahan yang ada di masyarakat.

Di sisi lain dengan perkembangan ilmu pengetahuan dan teknologi begitu cepat, memacu guru berusaha mengantisipasi dengan meningkatkan pengetahuan yang dimiliki untuk mengejar ketinggalan.

Pembinaan diharapkan dapat mencapai standart perform kemampuan profesional guru, sebagai berikut:

a. Menguasai bahan meliputi bahan bidang studi, isi buku teks dan kurikulum.

b. Mengasai bahan pendalaman, yang diwujudkan dalam mempelajari ilmu yang relevan, aplikasi bidang ilmu ke ilmu lain.

c. Mampu merumuskan tujuan pembelajaran yang berwujud ciri-ciri TPU dan TPK.

d. Dapat mengenal dan menggunakan metode mengajar dengan bentuk mempelajari macam-macam metode dan penggunaannya.

e. Mampu memilih dan menyusun prosedur pembelajaran yang tepat, yang berbentuk kriteria pemilihan materi dan prosedur mengajar sertamenggunakannya untuk merencanakan program pelajaran dan menyusun satuan pelajaran.

f. Mampu melaksanakan program belajar mengajar yang berbentuk mempelajari fungsi dan peran guru dalam instruksi belajar mengajar, menggunakan alat bantu dan lingkungan sebagai sumber belajar, memonitor proses belajar siswa dan menyesuaikan rencana program pengajaran dengan situasi kelas.

g. Mampu mengenal kemampuan anak didik melalui mempelajari dan mengunakan prosedur dan teknik untuk mengidentifikasi kemampuan siswa.

h. Mampu merencanakan dan melaksanakan pengajaran media melalui mempelajari faktor-faktor penyebab kesulitan belajar siswa, menyusun rencana dan melaksanakan pengajaran tersebut. 
i. Mampu mengatur tata ruang kelas untuk pengajaran dengan mempelajari macam-macam pengaturan dan kriteria penggunaan tempat duduk dan setting ruang kelas sesuai dengan tujuan.

j. Mampu menciptakan iklim belajar mengajar yang serasi dengan mempelajari faktor-faktor yang menggunakan iklim belajar mengajar, strategi dan produser pengelolaan kelas yang bersifat preventif dan kuratif.

k. Mampu mengenal, memilih dan menggunakan media dengan cara mempelajari macam-macam media, kriteria pemilihan media, menggunakan dan merawat media.

1. Mampu membuat alat-alat bantu sederhana dengan prosedur pengenalan bahan-bahan yang ada di lingkungan, mempelajari perkakas untuk membuat alat bantu dan mengunakannya.

m. Mampu menggunakan dan mengelola laboratorium dengan cara mempelajari cara menggunakan laboratorium, mempelajari cara aturan pengamanan kerja di laboratorium, berlatih mengatur dan merawat ruang laboratorium.

n. Mampu mengembangkan laboratorium dengan cara mempelajari fungsi laboratorium dalam proses belajar mengajar, mempelajari desain laboratorium, menilai keefektifan kegiatan laboratorium dan mengembangkan eksperimen baru.

o. Mampu menggunakan perpustakaan dalam PBM dengan cara mempelajari fungsi perpustakaan dalam PBM, mempelajari macam-macam sumber perpustakaan dan menggunakannya.

p. Mengasai landasan pendidikan yang berupa landasan filosofis, sosiologis, historis, psikologis dan hukum.

q. Mampu mengelola intraksi belajar mengajar, dengan mempelajari cara-cara memotivasi dan menggunakannya, mempelajari bentuk layanan dengan menggunakannya (Widjaja, 1991). 
Dari pendapat para ahli tersebut di atas dapat ditarik beberapa indikator profesi guru sebagai berikut :

a. Memiliki latar belakang pendidikan pada perguruan tinggi yang didasarkan dengan suatu kode etik;

b. Memiliki keahlian tertentu, standart pengetahuan dan ketrampilan khusus lainnya (sesuai profesi);

c. Mampu menjalankan tugas sesuai dengan tuntutan profesinya;

d. Mampu melaksanakan kegiatan berdasarkan profesionalismenya bukan secara amatiran;

e. Mampu mengembangkan keahliannya secara profesional dan berkelanjutan;

f. Mampu menunjukkan produktivitaskerja yang tinggi dan mutu karya yang semakin lama semakin baik dan kompetitif,

g. Memiliki solidaritas kelompok profesi yang tinggi.

Disamping itu ada beberapa yangmenunjang performa guru profesional, yaitu: kepribadian yang matang, motivasi, dedikasi penguasaan dan penegmbangan ilmu, otonomi, penelitian,kemampuan mengajar dan berkomunikasi, meningkatkan profesi, pengakuan masyarakat, bersifat layanan dan intensif (Kosasi, 1999).

\section{Hubungan Supervisi dan Profesi Guru}

Kepala sekolah sebagai supervisor sangat berperan bagi inovasi dan perubahan, serta sebagai pembuat keputusan. Kepala sekolah bertugas mempelajari dan mengidentifikasi berbagai kebutuhan dan masalah-masalah yang dihadapi sekolah serta berusaha untuk memecahkannya serta mengambil keputusna yang terbaik. Persoalan yang meminta perhatian kepala sekolah adalah bagaimana membina guru agar pembelajaran yang berlangsung di sekolah dapat berjalan dengan baik, mengalami perubahan dan peningkatan (Bafadal, 2000).

Pidarta (1999), mengungkapkan bahwa selain membina guru dalam proses mendidik dan mengajar, kepala sekolah sebagai supervisor juga 
membina pribadi, profesi dan pergaulan mereka dengan sesama guru maupun personalia lain yang berkaitan dengan pendidikan di sekolah.

Usaha-usaha perabaikan mengajar guru, pemahaman tentang kurikulum, penguasaan mata pelajaran, upaya peningkatan kualitas sistem pendidikan secara keseluruhan yang mengarah pada pencapaian tujuan pendidikan diupayakan, dengan cara meningkatkan kompetensi guru (Imron, 1995).

Untuk menjawab setiap tantangan dalam pembaharuan di bidang pendidikan, usaha-usaha tersebut tentu saja harus diteruskan dan kepala sekolah merupakan pimpinan yang paling diharapkan untuk melanjutkan pembinaan terhadap guru.

Wijaya (1996), mengatakan agar kepala sekolah melibatkan guru-guru yang dipimpinnya ikut berperan dalam setiap usaha pemerintah untuk meningkatkan mutu pendidikan dan pengajaran. Sedangkan masalah guru dalam proses pembelajaran akan selalu ada dan terus berlanjut, sehingga pembinaan dari kepala sekolah tetap bahkan akan terus dibutuhkan. Guru harus tetap tumbuh dan berkembang dalam jabatannya agar mereka senantiasi mampu mengatasi setiap kesulitan atau masalah-masalah yang dihadapinya dalam perkerjaan mereka sebagai seorang guru.

Boardman (dalam Gunawan, 1996) mengemukakan bahwa kepala sekolah sebagai supervisor mempunyai fungsi pembinaan, yaitu : (1) membimbing guru agar ia dapat memahami masalah-masalah dan kebutuhan murid serta membantunya dalam mengatasi masalah tertentu, (2) membantu guru dalam mengatasi kesulitan belajar murid, (3) membantu guru dalam kecakapan mengajar yang lebih baik dengan menggunakan berbagai macam metode mengajar, (4) membantu guru untuk memperkaya pengalaman belajar sehingga suasana pembelajaran dapat menggembirakan anak didik, (5) membantu murid mengerti makna dari alat-alat pelajaran, (6) menumbuhkan moral yang tinggi dalam melaksanakan tugas sekolah untuk semua staf, (7) memberi pelayanan terhadap guru agar ia dapat menggunakan seluruh 
kemampuannya dalam melaksanakan tugas, (8) melaksanakan kepemimpinan yang efektif dan demokratis.

\section{Kesimpulan}

Pada dasarnya supervisi menurut Roy adalah segala layanan yang diberikan kepada guru yang pada akhirnya menghasilkan peningkatan proses pembelajaran dan kurikulum. Hal demikian juga oleh Negley dan Evans (1993) bahwa pelayanan diberikan dalam bentuk bantuan sedemikian rupa sehingga guru dapat belajar bagaimana meningkatkan kemampuan kenirjanya untuk mencapai tujuan-tujuan pembelajaran yang ditetapkan bagi siswanya.

Oleh karena pada hakekatnya supervisi merupakan pemberian bantuan kepada guru, maka fungsi kepala sekolah berkaitan dengan membangkitkan motivasi dan kerjasama guru-guru demi kelancaran pembelajaran, mengembangkan pengetahuan dan keterampilan guru-guru, mengalang kerjasama antara sekolah dan masyarakat, semua ditujukan untuk meningkatkan kualitas pendidikan dan pembelajaran yang efektif.

Supervisi yang dilakukan kepala sekolah menunjukkan bahwa bantuan atau pembinaan yang diberikan kepada guru bukanlah bantuan yang membelenggu kreatifitas dan tanggung jawab guru, melainkan dengan bantuan itu justru dapat merangsang pertumbuhan tanggung jawab dan kreativitas kinerja guru. Dengan demikian kegiatan supervisi lebih efektif dari pada pembinaan dalam bentuk penataran, sebab supervisi membimbing langsung para guru dalam aktivitasnya sehari-hari. Apa yang diberikan oleh kepala sekolah dan guru senior selaku supervisor akan langsung dipraktekkan, kesulitan-kesulitan dapat segera dikonsultasikan dan diatasi, efek pelaksanaan menjadi umpan balik bagi aktivitas berikutnya, dan kepuasan kerja akan menjadi insentif bagi para guru untuk tetap bekerja dengan baik (Pidarta, 1999).

Dalam memberikan bantuan dan pembimbingan agar para guru bertumbuh dan berkembang dalam profesi mereka, maka supervisor perlu memperhatikan tingkat kemampuan guru yang dilayani. Guru kemampuannya 
rendah perlu pelayanan yang lebih insentif dengan cara yang mudah dipahami, sedang guru yang kemampuannya lebih diarahkan pada kinerja yang bersifat inovatif, sehingga potensinya makin berkembang lebih meningkat.

Agar kegiatan supervisi mencapai sasaran yang diharapkan, seorang supervisor harus mampu mengorganisasi guru. Mengorganisasi adalah mengatur, mengkoordinasi dan membina para guru agar mereka mau dan dapat bekerjasama, berpartisipasi aktif dalam mewujudkan cita-cita pendidikan di tempat bekerja mereka masing-masing (Pidarta, 1999). Dengan demikian kepala sekolah selaku supervisor harus mampu memotivasi guru sebagai tenaga pendidik yang professional yang memiliki komitmen pada tugasnya untuk mengutamakan pembelajaran pada siswanya.

Kepala sekolah selaku supervisor sudah selayaknya memberikan bantuan memotivasi dan mengikutsertakan guru dalam setiap kesempatan demi tercapainya tujuan pendidikan. Serta menciptakan suasana kondusif sehingga guru merasa aman dan bebas dalam mengembangkan potensi dan kretivitasnya yang dapat dipertanggung jawabkan demi kepentingan siswanya.

Perlu dipahami bersama bahwa masalah guru dalam proses belajar mengajar akan selalu ada dan terus berlanjut, oleh sebab itu bimbingan dari kepala sekolah akan selalu dibutuhkan oleh guru, sehingga diharapkan kemampuan profesiona guru terus berkembang. Pembinaan kepala sekolah yang terus menerus dan berkesinambungan berdampak positif terhadap tumbuh dan berkembangnya sikap profesional guru, yang ditandai dengan rajin bekerja, penuh pengabdian, kreatif dan menjunjung tinggi disiplin.

Dari paparan diatas menegaskan betapa pentingnya supervisi yang dilakukan kepala sekolah demi tumbuh dan berkembangnya guru-guru profesional di sekolahnya, sebagai partner kerja dalam memecahkan persoalan-persoalan edukatif dalam mencapai tujuan pendidikan sesuai harapan masyarakat. 


\section{Daftar Pustaka}

Arikunto, Suharsini, 2000, Manajemen Penelitian, Jakarta: Rineka Cipta

Bafadal, Ibrahim, 1992, Supervisi Pengajaran Teori dan Aplikasi dalam Membina Profesional Guru, Jakarta: Bumi Aksara

Bogdan, Robert, 1992, Introduction To Qualitative Research Methods, A Phenomenological Approach To The Social Sciences, New York: John Wiley and Sons

Bugin, Burhan, 2001, Metodologi Penelitian Sosial: Format-Format Kuantitatif dan Kualitatif, Surabaya: Airlangga University Press

Depdikbud, 1999, Pedoman Pelaksanaan Pada Pembahasan Sistem Pendidikan Tenaga Kependidikan di Indonesia, Suplemen 2 Buku II, Bidang Studi Bimbingan Konseling, Jakarta

Franseth, Jane, 1961, Supervision as Leadership, Peterson NJ: Evanstone and Row

Glickman, Carl D, 1981, Development Supervision: Alternatif for Helping Teachers Improve Instruction, Virginia: ASCD

Gunawan, Ary, H, 1996, Administrasi Pendidikan Mikro dan Supervisi Pendidikan, Jakarta: Rineka Cipta.

Hariwung, A.J, 1989, Supervisi Pendidikan, Jakarta: Depdikbud

Kosasi, Raflis, 1999, Profesi Keguruan, Jakarta: Rineka Cipta

Kundji, Zainur, H, 1998, Peran dan Strategi Kepala Sekolah Dalam Peningkatan Kualitas Guru SD, Malang: PPS-IKIP

Mantja, Willem, 1990, Supervisi Pengajaran dan Pembinaan Profesional Guru Sekolah Dasar, Malang: PPS-IKIP

Neagley, Ross, L, and N. Dean Evans, 1993, Handbook Of Effective Supervision Of Instruction, 4th Edition, New Jersey: Prentice-Hall , 1999, Pemikiran Tentang Supervisi Pendidikan, Cetakan kedua, Jakarta: Bumi Aksara

Purwanto, Ngalim, 1990, Administrasi dan Supervisi Pendidikan, Bandung: Rusdakarya

Riyanto, Yatim, 1996, Metodologi Penelitian Pendidikan, Surabaya: SIC 
Roy, W. Robert, 1967, Vocation and Practical Art Education: History, Development and Principles, New York: Hoper and Row Publisher.

Sahertian, Piet, A, 2000, Supervisi Pendidikan dalam Rangka Pengembangan Sumber Daya Manusia Pendidikan, Malang: FIP IKIP

Sergiovanni, Thomas. J, 1971, Emerging Patterns of Supervition: Human Perpectives, New York, Mc Grow - Hill Book Company

Soetopo, H., \& Soemanto, W, 1998, Kepemimpinan dan Supervisi Pendidikan, Jakarta: Bina Aksara

Sutjipto dan Mukti. B, 1992, Administrasi Pendidikan, Jakarta: Departemen Pendidikan dan Kebudayaan

, 1991, Peranan Kepala Sekolah Menengah Sebagai Pemimpin Pendidikan, Lembaga Penerbitan IKIP Malang

Tilaar, H. A. R, 1990, Prospek Perencanaan dan Manajemen Pendidikan Nasional, (Makalah) disampaikan pada Lokakarya Profesionalisasi Manajemen Pendidikan dalam Rangka Peningkatan Mutu Pendidikan Nasional, Jakarta, 24 November 1990 